\title{
CONTENT MANAGEMENT SYSTEM PEMBELAJARAN BERBASIS E- LEARNING BAGI SEKOLAH DASAR
}

\author{
Marlina, ST,MMSi \\ Jurusan Teknik Informatika Fakultas Teknik Universitas Persada Indonesia Y.A.I, l. Diponegoro no.74 \\ Jakarta Pusat,Email: linbahar@ymail.com
}

\begin{abstract}
Abstrak
Content management system merupakan suatu system yang digunakan untuk mengelola materi pembelajaran secara online. System ini memberikan manfaat bagi pihak sekolah teruma admin, guru dan siswa. Kegiatan pembelajaran ini membahas materi ajar yang dapat didownload oleh siswa dan siswa dapat mengerjakan materi secara online dan mendapatkan score hasil yang didapatkan. Sedangkan pihak admin dapat memasukan data siswa, data guru dan materi ajar serta kategori soal. Dan guru dapat melihat profile guru, dan memasukan materi pelajaran dan soal tambahan.
\end{abstract}

\section{Kata kunci : CMS, admin, siswa, guru, materi ajar, soal ujian}

\section{Pendahuluan}

Penelitian ini membahas mengenai

Content Management System untuk pembelajaran berbasis online bagi siswa-siswi sekolah dasar. Content ini biasanya untuk mengelola dan memfasilitasi proses pembuatan, pembaharuan, dan publikasi content secara bersama (colaboration content management). Content mengacu pada informasi dalam bentuk teks, grafik, gambar, maupun dalam formatformat lain yang perlu dikelola dengan tujuan memudahkan pembuatan, pembaharuan, distribusi, pencarian, analisis, dan meningkatkan fleksibilitas untuk ditramformasikan dalam bentuk lain. Jadi, Content Management System (CMS) adalah sebuah sistem yang dapat membuat, mengatur, mendistribusikan, mempublikasikan dan menjaga informasi perusahaan atau institusi, dimana admin tidak harus mengetahui tag HTML untuk menjalankanya. Penelitian ini telah beberapa peneliti yang melakukannya,diantaranya 1) Jurnal teknologi informasi oleh Chrisna Atmadji, M.Arif Soeleman, 2) website dunia belajar, 3) Jurnal penelitian kependidikan oleh Endah Tri Priyatni

Metode pembelajaran yang secara online yang ditawarkan mengenai conten pembelajaran dengan memudahkan guru dalam memberikan materi ajar pada conten yang telah tersedia beserta contoh, dan guru dapat pula memberikan latihan-latihan soal untuk dikerjakan oleh siswa-siswi di sekolah dasar, dan hasil latihan-latihan yang telah tersedia tersebut dapat memberikan penilaian mengenai keberhasilan siswa dalam mengerjakan latihan yang telah ada di portal (website) tersebut. Tujuan dari metode pembelajaran ini untuk mempermudah guru, siswa dan admin dalam memberikan pembelajaran tanpa adanya batasan waktu dalam kegiatan pembelajaran. Pembahasan penelitian ini menampilkan kebutuhan user yaitu admin, dimana admin dapat memasukan data siswa, data guru, materi pelajaran, kategori mata pelajaran, dan soal-soal ujian.

\section{Tinjauan Pustaka}

Selama ini mata pelajaran diberikan dengan cara konvensional yaitu kegiatan lebih banyak dilakukan oleh guru (belajar mempersiapkan kuliah presentasi di depan kelas, menyiapkan materi ajar, menyiapkan ujian dan mengoreksi jawaban hasil ujian sedangkan siswa cenderung pasif (mendengarkan mata pelajaran, mencatat, belajar dan ujian). Disis lain perkembangan teknologi belajar dan pembelajaran sudah mengarah pada penggunaan teknologi informasi untuk meningkatkan kompetensi lulusan secara nyata melalui kegiatan belajar yang lebih efektif dan berpusat pada siswa (student central learning). Pemberian mata 
pelajaran secara konvensional dianggap kurang efektif sebab siswa cenderung pasif, siswa hanya mendengarkan dan mencatat ceramah guru. Di sini justru guru yang lebih efektif belajar padahal seharusnya aktifitas pembelajaran lebih banyak dilakukan oleh siswa.

Dari hasil pengamatan peneliti menunjukkan bahwa pembelajaran yang dilakukan dikelas berorientasi pada tahap-tahap pembukaan-penyajian-penutup. Pada kegiatan pembelajaran ini, guru cenderung menggunakan metode ceramah dengan sedikit disertai tanya jawab. Guru berusaha memindahkan atau mengkopikan pengetahuan yang ia miliki kepada siswa. Keadaan ini cenderung membuat siswa dalam menerima pelajaran dari guru.

Kegiatan pembelajaran yang tergambar diatas merupaakn kegiatan pembelaajran yang bertentangan dengan ide yang dilontarkan Vigotsky (dalam Slavin, 1994: 48 ) berupa scaffolding yaitu pemberian bantuan sebanyakbanyaknya kepada seseorang anak selama tahaptahap awal pembelajaran kemudian mengurangi bantuan tersebut dan memberikan kesempatan kepada anak untuk mengambil alih tanggung jawab yang semakin besar segera setelah ia dapat melakukannya.

Umumnya, sebuah CMS (Content Management System) terdiri dari dua elemen:

1. Aplikasi manajemen isi (Content Management Application[CMA])

2. Aplikasi pengiriman isi (content delivery application [CDA])

Terdapat banyak sekali CMS di dunia open source saat ini, beberapa diantaranya yang cukup populer dan memiliki fitur yang lengkap adalah Drupal, Joomla dan Xoops. Masing-masing memiliki ke khasan dan kekayaan modul tersendiri.

Dalam perancangan conten dapat menggunakan metode Quality Function Development (QFD) yang daapt diaplikasikan untuk memperoleh spesifikasi desain yang sesuai dengan tujuan perancangan quality function deployment berupa metode untuk menjamin bahwa spesifikasi desain sejalan dengan keinginan konsumen. Untuk itu tujuan dari QFD adalah untuk mendapatkan karakteristik harga teknis dari suatu produk atau service design QFD biasanya dikembangkan untuk aplikasi industry. Namun telah ada yang mengaplikasikannya di dunia pendidikan menggunakan QFD untuk menghitung dan untuk merespon kebutuhan departemennya dan lain-lain.

\section{Hasil dan Pembahasan}

Perangkat lunak content management system merupakan system yang memanfaatkan internet untuk menyampaikan materi pembelajaran yang memenuhi kebutuhan individual siswa. Perangkat lunak ini akan digunakan oleh tiga kategori pengguna yaitu administrator, guru dan siswa. Gambaran umum perangkatn lunak content management system dapat dijelaskan dibawah ini :

1. Administrasi dapat melakukan :
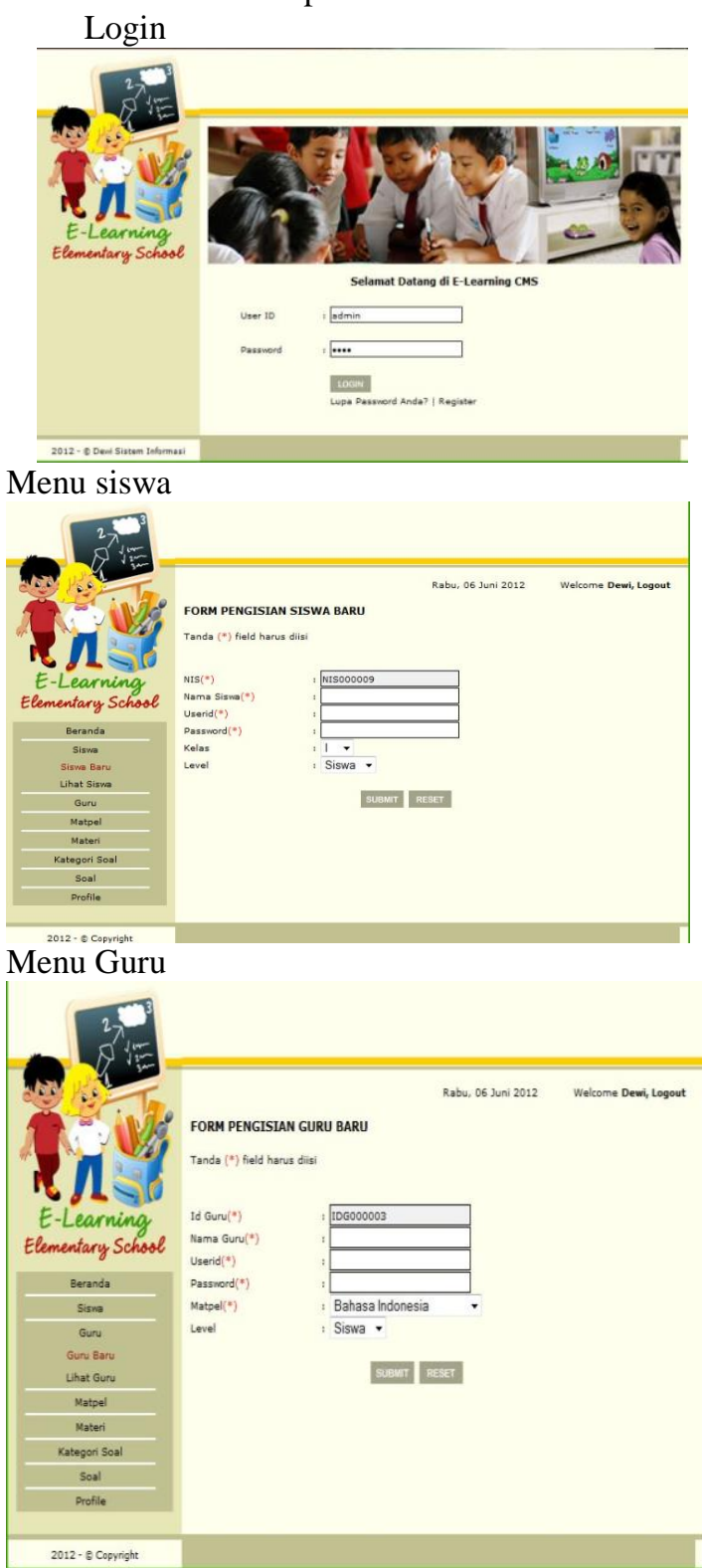

Menu Mata pelajaran 

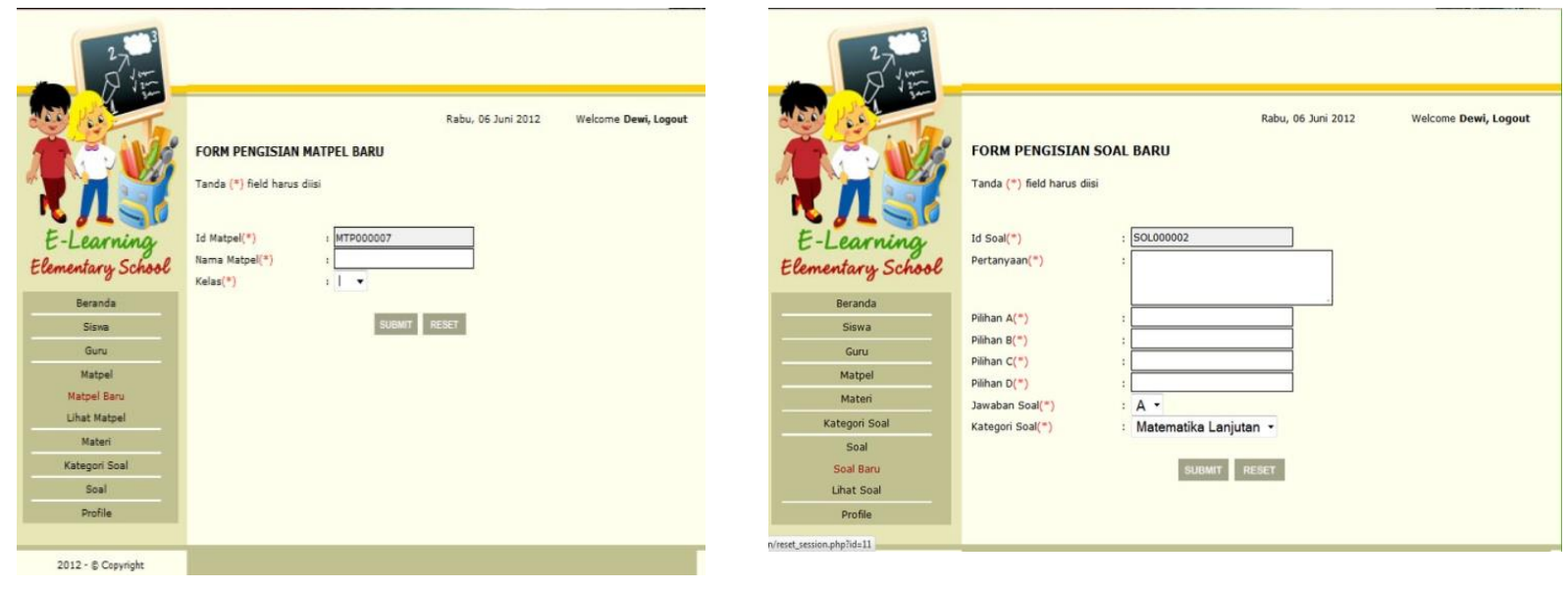

Menu Profile
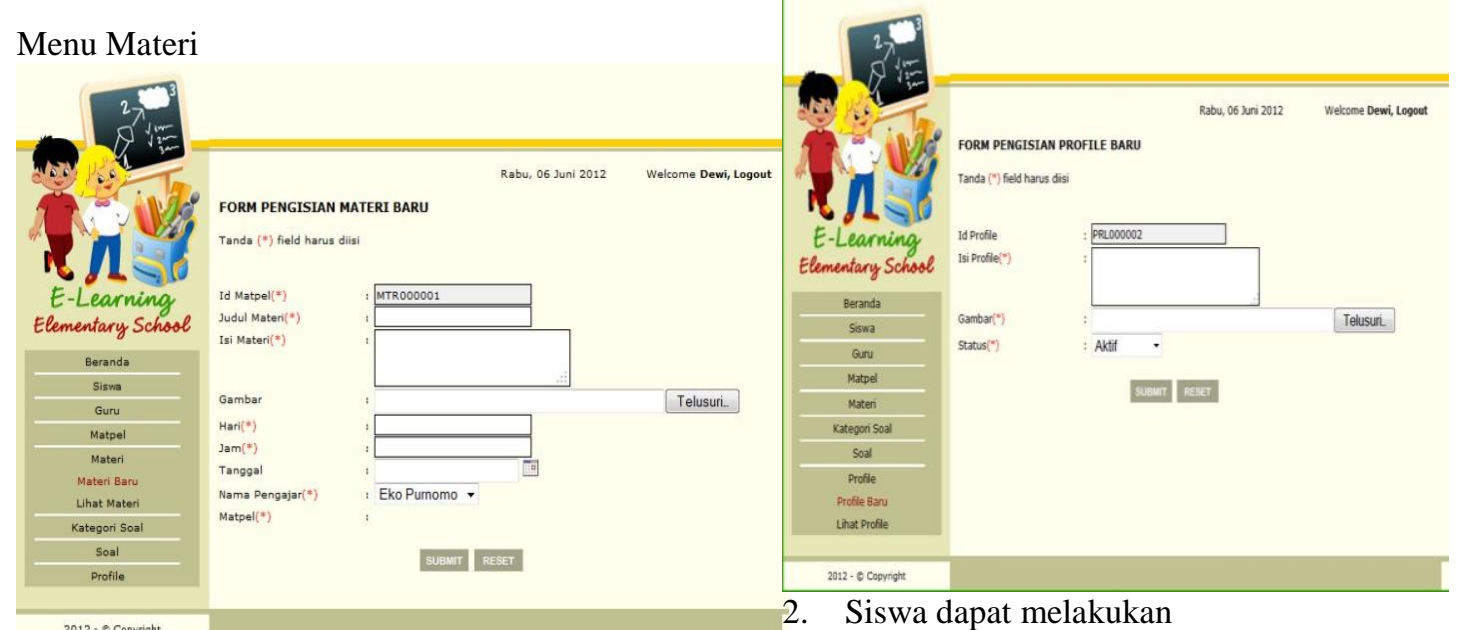

2. Siswa dapat melakukan

Menu Kategori soal baru

Menu login

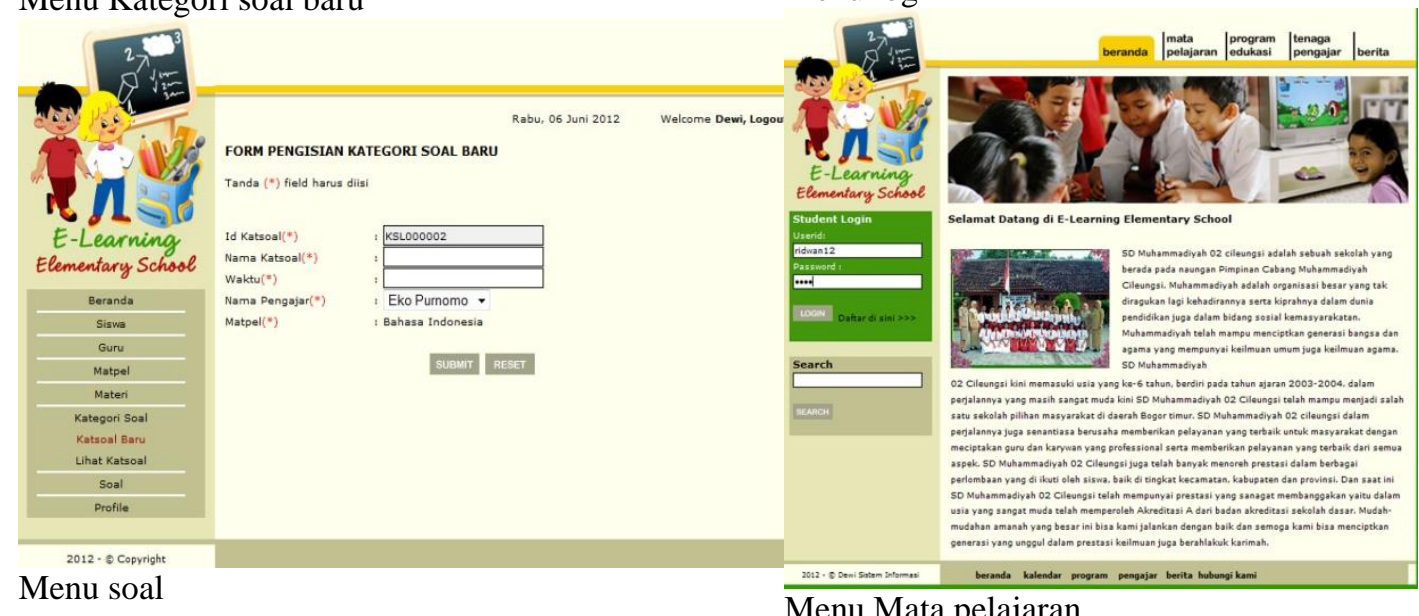

Menu Mata pelajaran 


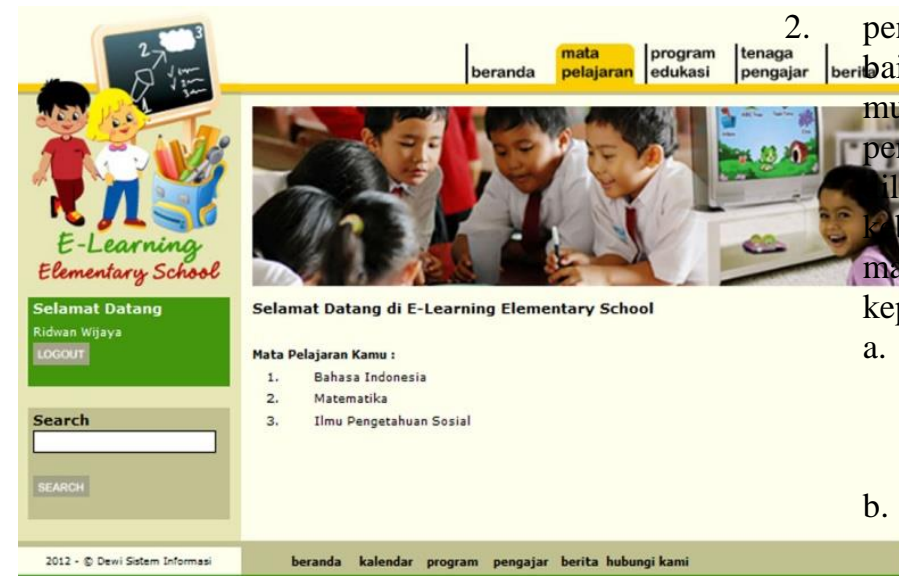

\section{Kesimpulan}

Hasil penelitian ini dapat membantu pihak sekolah terutama pihak administrasi, guru dan siswa. Kesimpulan yang didapat dari penelitian ini adalah :

1. aplikasi content management system ini berguna untuk mempermudah guru dalam mengelola materi pelajaran dan soal ujian yang akan diberikan kepada siswa

\section{Daftar Pustaka}

[1] Chrisna Atmadji, M. Arief Soeleman, Jurnal Teknologi Informasi, Volume 6 Nomor 1, April 2010, ISSN 1414-9999

[2] www.duniabelajar.com

[3] Endah Tri Priyatni, Jurnal penelitian kependidikan, Th 20, No.2, Oktober 2010.

[4] Anhar, ST. Panduan Menguasai PHP dan MYSQL secara Otodidak , Penerbit Mediakita, Edisi 2 Jakarta, 2010.

[5] Hakim, Lukmanul. Bikin Website Super Keren dengan PHP dan JQuery. Penerbit Lokomedia Yogyakarta 2010.

[6] Hariadi, Sandi.Trik dan Solusi Jitu Pemrograman Web, Penerbit Lokomedia Indonesia Yogyakarta, 2010.

[7] Irwanto, S.Kom, MM, Djon, Perancangan Object Oriented Sofware dengan UML. Penerbit ANDI Yogyakarta. 2006. penyampaian materi pembelajaran yang eribaik pada suatu kelas maya tidaklah mudah. Dengan aplikasi CMS penyampaian materi pembelajaran dapat lakukan dengan lebih baik sesuai dengan butuhan siswa. CMS dapat memberikan materi pembelajaran yagn terpesonalisasi kepada siswa melalui 2 cara yaitu :

a. penyampaian materi pelajaran dilakukan dengan pemantauan materi siswa dengan materi pelajaran yang diberikan secara online.

b. Penyampaian materi pelajaran disesuaikan dengan level siswa saat ini sehingga diperlukan proses evaluasi untuk mengukur tingkah kemajuan siswa.

3. Proses evaluasi yang terdapat pada aplikasi CMS berguna bagi guru untuk mengetahui tingkat penguasaan siswa terhadap suatu materi pembelajaran sehingga dapat membantu guru untuk menganalisis kejelasan, relevan dan keefektifan dari materi pembelajaran tersebut.

[8] Maulana, Murad. Membangun Website Dinamis Tanpa Background IT dengan CMS Drupal 6.0. Penerbit Andi Yogyakarta 2009.

[9] Kadir, Abdul. Mudah Mempelajari Database MYSQL. Penerbit ANDI Yogyakarta. 2010.

[10] Komputer, Wahana. Mendesain Website Dinamis dan Menraik sengan Adobe Dreamweaver CS4. Penerbit Andi Yogyakarta. 2010.

[11] Komputer, Wahana. Paling Dicari PHP Source Code. Penerbit ANDI. Yoyakarta . 2010.

[12] Kurniawan, Heri. Trik Membuat Web Template Dengan PHP dan CSS. Penerbit Lokomedia. Yogyakarta . 2011.

[13] Permana, Lucky. Panduan Lengkap Website Dinamis. 
Penerbit indie-Publishing Jakarta. 2010.

[14] Puspitosari, Heni A. Pemrograman Web Database dengan PHP dan MYSQL. Penerbit Skripta. Malang . 2011.

[15] Suprianto, Dodit. Joomla Webmaster Panduan Mudah dan Lengkap Membuat Website Profesional. Penerbit Oasemedia. Bandung

[16] http://www.scribd.com/doc/8687
989/Kualitas-Informasi

[17] http://shodiqnote.blogspot.com/2 011/01/beberapa-istilah-database.html

[18] http://ekoindri.wordpress.com/tut orial-pemula-istilah-database/

[19] http://lecturer.ukdw.ac.id/othie/d atabasefundamental.pdf

[20] http://blog.its.ac.id/dyah03tc/200 7/10/05/basis-data-database/

[21] http://blog.re.or.id/erd-entityrelationship-diagram.htm 